\title{
Post-prison resocialization - myth or reality?
}

\author{
R. A. Romashov ${ }^{1,2}$, E. A. Bryleva ${ }^{3}$ \\ ${ }^{1}$ St. Petersburg Humanitarian University of Trade Unions, \\ 15, ul. Fuchika, St. Petersburg, 192102, Russian Federation \\ 2 Institute of Economics and Law of Petrozavodsk State University, \\ 33, pr. Lenina, Petrozavodsk, 185910, Republic of Karelia, Russian Federation \\ ${ }^{3}$ Perm Institute of the Federal Penitentiary Service of Russia, \\ 125, Karpinsky ul., Perm, 614012, Russian Federation
}

For citation: Romashov, Roman A., Bryleva, Elena A. 2019. "Post-prison resocialization - myth or reality?” Vestnik of Saint Petersburg University. Law 4: 827-835.

https://doi.org/10.21638/spbu14.2019.414

\begin{abstract}
In this article, the authors draw attention to the consistently high growth of recidivism among those who returned from prison. The reasons for this are insufficiently effective re-socialization activities, while the authors point out that the activities of the Federal Penitentiary Service in prisons during the prison period are currently the most streamlined both in terms of regulatory legal support and in technical and legal terms. The main problems arise for convicts upon returning from prison, which is associated with the loss of social ties; difficulties in finding a job, while the state represented by authorized bodies and officials, in fact, distances itself from the process of post-prison resocialization. The authors in the process of the study point out the following issues that need to be resolved both at the legislative and administrative levels: the formation of common approaches in defining the concept of "resocialization", "probation", as well as in developing common requirements and standards in the field of post-prison resocialization. The authors conclude the need for an integrated approach to the re-socialization of convicts with the involvement of civil society institutions and refer to the historical past of the Russian Empire, in particular, patronage societies that are quite effective at that time. The authors have noted positive examples of concrete practical assistance to people who have returned from places of detention, in particular such organizations are the Center for the Promotion of Criminal Justice Reform.
\end{abstract}

Keywords: resocialization, convicts, Federal Penitentiary Service, state, civil society, societies patronage.

1. Introduction. The analysis of statistical and operational data of the Ministry of Internal Affairs of the Russian Federation confirms rather high level of recurrent crime among the persons which came back from places of detention. The Commissioner for Human Rights in the Russian Federation Tatyana Moskalkova noted that in the country the problem of socialization of the people who served sentence is particularly acute. "To me complaints constantly arrive that the person with criminal record cannot find a job. [Federal service of execution of the punishment (further - FSIN)] should strengthen work in this direction". The Prosecutor General's Office also considers that educational work in detention centers is carried out insufficiently well - for example, chiefs of groups pay not enough attention to psychological state of wards. Human rights activists note that after

(c) Санкт-Петербургский государственный университет, 2019 
release, convicts often cannot find work and return to a criminal way. All these structures, certainly, are right in the statements, but it is represented that resocialization is not only a task of the Federal Penitentiary Service which employees in the majority honestly treat execution of the duties, and the system systematic joint activity of the state and civil society directed to socialization of this category of citizens or as noted professor B. D. Parygin of "humanization of man" (Parygin 1971, 27).

2. Main research. The purpose of post-prison resocialization is preservation and restoration of social communications of the convict (the suspect, the defendant) with normal "free world". During post-prison resocialization, it is important to create personal conviction of the convict that the prison is not "the end of life and years which are not thrown out from life", and a certain vital stage, a peculiar lesson, and for some minors perhaps even an indicator of quality of life which worthy perception the course of life after the termination of term of punishment directly contacts.

To the staff of institutions criminally - an executive system (further - penal correction system) and also all that who is in a varying degree connected with the person preparing for release, or recently released it is necessary to conduct on the one hand the work directed to consolidation of the lawful bases of resocialization (the organization of correspondence and appointments with the family; labor involvement; educational and spiritual and moral activity, etc.), and on the other hand to interfere with "criminal infection" of the person.

The called stages of resotsializatsionny activity during the term of prison isolation are carried out directly in penal correction system institutions and at the moment are the most ordered both in respect of standard legal support, and in the technical and legal relation.

The relation to post-prison resocialization as process of "return of the stray son / daughter to society", assumes that after the release the person does not remain alone with itself and continues to act as an object of positive attention and at the same time administrative control from those who are directly interested in its return to normal/lawabiding life. As it was already noted such function of the interested person during prison socialization, the FSIN in the person of the staff of institutions of social isolation carries out. The interest of the last is obvious, than the big tendency to correction will be shown by the convict (the defendant, the defendant), that to a lesser extent it will break the mode of prison activity and, respectively, to cause problems to the management of institutions which efficiency of activity, in general is defined by ability to keep an order and calm in the "prison farms" entrusted to them.

After release of the person, the situation changes radically. Now in cooperation with former "sidelets", none of representatives of the state are directly interested. It is necessary to recognize that law enforcement agencies and special services interest not those who can follow a difficult and thorny way of "return to sources of good and justice", and those who plan and commit crimes. As for economic entities, for them former "convict", first of all different source of abuses as practically any inhabitant with confidence says that "the former criminals are not". It turns out that having received freedom, the person receives problems with which not much people help to cope to him in reality. At the same time the state represented by authorized bodies and officials, actually separates from process of post-prison resocialization, being limited to declarations that "society with understanding and trust has to treats the former criminals". 
There is a situation when one hostile environment ("the prison world"), is replaced by other, not less aggressive situation of "the free, but not kind world". The person who was practically under full patronage of the state until recently (questions of accommodation, hygiene, food, medical care, etc.) systemically decided at the level of institutions criminally - an executive system (further - penal correction system), it is provided to himself and deprived of a little significant social support. The lack of real interaction between FSIN, law-enforcement structures, the state and municipal executive authorities, as well as suspense of primary questions in the field of "a minimum of human dignity" (lack of housing, work, stable positive social relations, etc.) in some cases cause a penitentiary recurrence and "return" of the person in unpleasant, however already habitual and from that less dangerous conditions of "prison life". Unlike society which, not especially thinking of the "postponed" consequences tears away as a foreign matter, the person with "the low level of social responsibility", the prison system readily accepts it back and provides with "prison service", rather decent in terms of material and financial expenses.

As it was already noted, the processes of prison socialization and post-prison resocialization which are taking place in institutions of FSIN in general have ordered character that is explained by direct interest of staff of penal correction system in achievement of the positive results connected with providing an internal order and tranquility among special contingent. When it comes about the open system of society outside prison institutions, there is a mass of unresolved questions.

First, standard regulation of various aspects of process of return of convicts to society is carried out both on federal, and at the regional level within and legislative and bylaws. At the same time, Article 182 Criminally - the executive code of the Russian Federation (further - penal correction system of the Russian Federation) establishes that released "have the right for the labor and household device and receiving other types of the social help according to the legislation of the Russian Federation and regulations". From this with evidence follows that uniform requirements and standards in the sphere of postprison resocialization have to be established at the federal level. It is obvious also that semantic loading of the term "resocialization" is obviously not limited to receiving the social help, including the labor and household device. However follows at once will be defined, whether so it from the legislator's position.

The analysis of the current legislation confirms use of various terms in a varying degree characterizing activities of the state and public institutes and also the persons who served sentence for formation (restoration) of positive social links and right obedient behavior as synonymous, interchangeable semantic designs: "resocialization", "probation", "social adaptation and social rehabilitation", "social adaptation and resocialization".

We believe that these terms are not synonyms neither on language, nor by the legal nature. The frame decision of the Council of the European Union 2008/947/PVD of November 27, 2008 about use of the principle of mutual recognition to court verdicts and decisions on a probation for the purpose of implementation of supervision of execution of measures of a probation and alternative sanctions (The frame decision of the Council of the European Union 2008/947/PVD, 2008) specifies that measures of a probation mean the obligations and instructions put by competent authority on the natural person according to the national legislation of the taken-out state in connection with punishment with an execution delay, suspended sentence or conditional release. This frame decision indicates the taken probation measures which include, inter alia, requirements concerning 
behavior (such as alcohol intake termination duty), the residence (such as duty of change of the residence in connection with threat of causing domestic violence), education and training (such as duty of visit of courses of safe driving), activity in free time (such as duty of the termination of occupation or visit of competitions of certain sports) and restrictions or types of professional activity (such as obligation of search of professional application in other working environment; this obligation does not include supervision of observance of any professional disqualifications put on a face as a part of the sanction), it is possible to tell with full confidence that in a certain measure a punishment measure similar to our conditional condemnation to assignment of duties.

In the Rules of the Council of Europe about a probation adopted within the recommendation of CM/Rec (2010) of Committee of ministers to member states, the concept "probation" is included by a "wide range of actions and measures of educational influence, such as supervision, control and assistance which aim involvement of the convict in public life and also safety of society". Social adaptation within the mentioned Rules means, "rendering the constructive systematic help in return of the convict to society, implementation of supervision of it on a voluntary basis after release from imprisonment serving". At that supervision as assistance in social adaptation, Rules separate from "post-penitentiary control" as implementation of the administrative supervision provided by the law for released from places of detention (Rules of the Council of Europe, 2010).

The concept of long-term social and economic development of the Russian Federation until 2020 approved by the Order of the Government of the Russian Federation of November 17, 2008 No. 1662-r as one of the directions indicates "forming of an effective system of social support of the persons which are in a difficult life situation and the systems of prevention of offenses, including: creation of service of the probation providing social and psychological escort of the persons released from places of detention and rehabilitation saturation of sentences of vessels regarding realization of coercive measures of educational influence, implementation of technologies of recovery justice and holding conciliatory procedures", respectively, we can say that rather social functions, than supervision functions are allocated for this body.

The draft federal law "About a Probation in the Russian Federation and the System of Bodies and Organizations It Carrying Out" uses semantic construction "social adaptation and social rehabilitation" which is understood "as process of active adaptation of the persons which underwent criminal prosecution, appeared in a difficult life situation and needing preservation or restoration of socially useful communications to the rules and standards of behavior adopted in society and also restoration of their broken social communications and functions". Within uniform definition the legislator does not divide adaptation and rehabilitation.

In the existing normative legal acts subjects of law-making operate with a design "social adaptation and resocialization", "active resocialization", without fixing legal definition of these concepts at all.

If we speak about post-penitentiary maintenance and social adaptation, we will agree with D. N. Sergeyev whether "it makes sense to borrow to the Russian legal system the alien term and not absolutely precisely transferring plan of developers of the bill" (Sergeyev 2013, 68), considering that the conducted survey among employees criminally - an executive system and other law enforcement officers showed that most of them does not understand value of this institute. You should not forget that in the operating system of bod- 
ies criminally - an executive system exist criminally - executive inspections, and lawenforcement bodies exercise administrative supervision as "observation of observance by the person released from the places of detention set by court of temporary restrictions of its rights and freedoms and also behind performance of duties by it".

The lack of the unified standard terminology complicates legal regulation of process of resocialization of convicts as does not allow to answer a number of key questions: "How prison socialization, post-prison resocialization, penitentiary adaptation, resocialization and a probation correspond", "What is the beginning and what - the end of process of post-prison resocialization?", "What stages of this process?", "What activities and procedures are included in this process?", "Who treats subjects and what is object of process?", and, at last, "As it is possible to define efficiency of process?". Depending on answers to these questions also change of the departmental regulatory base is possible.

The V-second, it is necessary to pay attention to the next moment. The existing state programs provide implementation of a complex of actions for creation of conditions for training of the released persons for further social adaptation through service of a probation (as emergence of such service is provided by the Concept of long-term social and economic development of the Russian Federation until 2020 approved by the order of the Government of the Russian Federation of November 17, 2008 No. 1662-r). However in the list of measures of legal regulation in the sphere of implementation of these state programs information on adoption of legal acts of a probation neither in short-term, nor does not contain in the medium term.

The following complex of questions is connected with process of interaction of penal institutions with the state and non-state actors in the course of preparation for postprison resocialization. At the regional level, level of local government and within departments the significant place in the system of legal regulation of this process is taken by target programs. So, for example in the Samara region the regional target program "About Assistance to the Persons Who Served Prison Term and to the Persons Condemned to Measures of Criminal Character without Isolation from Society and Assistance of Their Social Rehabilitation" providing the essential volume of target financial investments works. Among collaborators of the program there is a number of regional executive authorities: regional Department concerning ensuring public safety, the Ministry of construction, the Ministry of Health, the Ministry of social and demographic development, the Ministry of Education and Science, etc. As the subjects participating in realization of actions for the directions of the Program territorial structures of federal departments (Federal migration service (further - FMS), FSIN, the Ministry of Internal Affairs), local governments, municipal authorities, non-profit organizations are attracted (Romashov, Arbuzova 2013).

Paying tribute to importance of target financing of the sphere of social rehabilitation of the persons who served criminal penalty it should be noted nevertheless that the existing target program contains in the structure a number of provisions which performance, as well as their influence on achievement of the goals and Program tasks, it is impossible to measure by instruments of financial control (for example, implementation of a package of measures for preservation and restoration of family relations of the persons which are in places of detention; assistance in reduction of terms of recovery of documents to the persons condemned without isolation from society, etc.). Authors of the document called such positions on "implementation of a package of measures", "to assistance..." reference 
materials, however included them in number of actions for realization of tasks of the target program.

Also such task of the Program as improvement of a regional regulatory framework concerning adaptation of the persons released from places of detention and the persons condemned to measures of criminal character without isolation from society attracts attention. As forms of the actions promoting achievement of this task - holding seminars, meetings, round tables and development of the interdepartmental agreement. But financing of similar actions is carried out within primary activity of performers! Thus, the target program contains a task which solution is financed by other mechanisms.

Performing functions on training of convicts (defendants, defendants) for release, the staff of institutions of FSIN of Russia interacts with divisions of FMS, the Ministry of Internal Affairs and the Ministry of Justice. Positive dynamics is observed in a question of documenting of convicts. Joint efforts succeeded to achieve reduction of number of the persons released from correctional facilities in which personal records passports are absent or are invalid.

At the same time, the problem of interaction of staff of penal correction system and Law-enforcement bodies on places regarding work with inquiries concerning the persons which are released from places of detention is particularly acute. According to reports of Main department FSIN of Russia on the Samara region, the percent of inquiries on which of law-enforcement bodies the answer did not arrive remains steadily high.

It is obvious that the lack of information, the request for which came to law-enforcement bodies, does not allow employees of groups of social protection to organize effectively further interaction with subjects of the social environment concerning the labor and household device of the released person as it is necessary to have, at least, authentic data on where and to whom the convict is released.

Has no sufficient legal regulation and interdepartmental interaction concerning preparation for release of convicts - foreign citizens. According to the Instruction about rendering assistance in the labor and household device and also assistance to the convicts exempted from serving sentence in correctional facilities of penal correction system, the staff of institutions of execution of punishments has to notify local governments, the employment services at the chosen place of residence on the forthcoming release of the convict, existence at it of housing, his working capacity, the available specialties; to send requests for a possibility of accommodation to the chosen address. In relation to the territory of the foreign states are absent given about the addressees of the address who are representatives of local authorities. Embassies and consulates, as a rule, do not respond to such notices and inquiries. Features of an order of preparation for release of the convict having nationality of other state in details in regulations are not regulated.

Thus, we believe that the legislator needs to decide on understanding of this legal institute that we mean: post-penitentiary maintenance and social rehabilitation, concerning minors carrying out recovery technologies or is about introduction of additional duties to the discretion of the court.

The listed problems are only a small part of those questions without which practical solution post-prison resocialization will continue treats the phenomena, so widespread in Russia, about the importance and importance of which tell much including at the highest levels, however real functions according to the solution of the existing problems leave to those who in fact is directly interested in the solution of these problems. Here also it turns 
out that to a great regret relevant the thesis which was formulated about a century ago by the Great schemer Ostap Bender in the field continues to remain: "Business of rescue of drowning - work drowning".

At the same time it is considered to be that only at the present stage of development of society the state attended to problems of the former convicts, however in the conditions of globalization and the aspiration of the Russian Federation to observe the international standards, certainly, expediently to adopt positive experience of other countries, however certain "forgetfulness" of the developed historical penitentiary traditions is obviously not good development of the state.

So, Russian experience and the ideas of such scientists as S. K. Gogel and G. S. Feldstein, P. I. Lyublinsky, etc. formed the basis of development of the ideas of societies of patronage in Russia which received positive terazvitiye during $19^{\text {th }}$ - the beginning of the $20^{\text {th }}$ centuries. Mikhail Mikhaylovich Borovitinov, the famous Russian lawyer, the jurist since 1908 heading department of criminal law in Imperial school of jurisprudence and a meeting being the assistant to the chief of the Head prison department in 1901 pointed to members of the International Union of criminalists that there are 2 views of patronage: "as on a special type of the help, unbound and as the last link, an extreme stage of a system 'learning of the person to use freedom"' (Borovitinov 1908, 49).

Really, activity of data of societies deserves attention and fixed studying. Without going deep especially into historical aspects of creation, organizational creation of data of societies I will stop more on the conceptual ideas: First, the help was carried out address: food, clothes, contempt in diseases, the help in correction of documents, money, that who needs it. So, the Charter of the Ryazan society of protection the persons released from jails specified that "activity of Society is expressed: in supply of the persons accepted by it under the protection, clothes, food, medical grants, working tools, materials and others objects, useful to them; in issue to them of loans and allowances; in cares and a search for the marked persons of occupations and providing places to them; in assistance to their room in shelters, hospitals, schools, shelters, houses of diligence and or cheap apartments; in taking measures to the fastest receiving by the marked persons of residence permits; in excitation before the power concerning the marked persons if they are subject after departure of punishment to restrictions in the right of election and change of the residence, petitions for permission of privileges; in assistance in the relation of election and change of the residence, about an exception of residence permits of marks about criminal record and about permission to follow to the destination; in assistance to the marked persons after release them from jails in departure home; in facilitating and bringing them to the education of children, as well as other similar measures and actions directed to persons under the protection of Society" (The charter of the Ryazan society of protection the persons released from jails (patronage), 1912).

Secondly, it was helped also families of prisoners and children of prisoners. The priest Grigory Rybalsky for departure of prayers in the Simferopol prison castle trained in the diploma of juvenile children of adult prisoners, delivering for this purpose necessary books, personally from himself and also during seven-year service at a jail supplied competent prisoners for reading to books spiritually - moral contents from own means, forwarded more than 40 such books in the lock, without earning at the same time any salary (State archive of the Russian Federation, fund 123, op. 1, d.398, 1. d. 1). 
Thirdly, it is possible to speak about change of the attitude towards the criminal and prison business. The prosecutor of the Nizhny Novgorod district court in the report in prison committee noted: "To reconcile society with the criminal, having supported him and to direct to a true way and makes the main objective of special institutions - prison patronage (Central archive of Nizhny Novgorod region, fund 386, op. 1, d. 28, 1.13).

Society had both state, and private means. State arrived from district treasuries, from City Councils or town halls, they were spent for food, clothes, hospitals, the maintenance of prisons. Private funds consisted of annual and one-time donations of benefactors, property and money given to the "Wake of the soul", mug fees in prisons, churches, shopping areas. Everyone was invited to do good for the sake of improving the detention of prisoners in prisons (Varentsova, Varentsov 2011). Studying of archivings of the middle of the $19^{\text {th }}$ century confirm the regular additional donations which are carried out by members of prison committees, in particular repeatedly in a positive side it was noted Perm, Oryol, etc. prison committees (State archive of the Russian Federation, fund 123, op. 1, d. 398, 1. 1); some given made even wills in favor of prison prisoners (State archive of the Russian Federation, fund 123, op. 1, d. 14, 1. d. 1). The director of the committee, Yaroslavl provincial popechitelny about prisons, hereditary honourable citizen Sorokin for 1869 offered, apart from management contributions of 700 rubles (the sum for those times very impressive), at the same time the director made on own account considerable corrections in a jail, tried about decoration of prison church and bought economic things at own expense (State archive of the Russian Federation, fund 123, op. 1, d. 398, 1. d.29). It is necessary to tell that such work did not remain unnoticed from the state. In total for 1868-1869 on representation of Governors about 26 people were encouraged with awards and St Ann's medals, St. Stanislav and St. Vladimir with carrying on a tape.

Now active revival of charity begins. So, according to Rosstat, in 2017 in Russia there were more than 9600 charity foundations and about 1700 charitable organizations (movements, institutions).

Funds of both all-federal, and regional character work for the condemned persons. In particular a positive example is the Center of assistance to reform of criminal justice the oldest human rights organization which deals with problems of prisoners, of criminal justice and execution of the punishment, created in 1988 by Valery Abramkin who was the political prisoner, one of the purposes of which is social, psychological and legal aid by the condemned minor. I will note that this Center unlike other organizations renders the concrete practical help. So, for example the staff of this center supervises the released minors following in transit through Moscow, conducts tours, and sees off on the following transport.

3. Conclusions. Thus, participation of civil society in post-prison resocialization and not only in terms of generosity and nobility is represented obvious what always was a part of the Russian mentality, but also with a certain share of healthy pragmatism, considering that this category with return to ranks of law-abiding citizens will not be more burden for the budget and will not begin to constitute potential danger to society, respectively, with full confidence it will be possible to claim that post-prison resocialization is an actual state of the public relations of the Russian state, the whole complex system of interaction of bodies of the state and civil society. 


\section{References}

Borovitinov, Mikhail M. 1908. Lectures on criminal law, Comp. A. I. Krasovsky. St. Petersburg. (In Russian) Parygin, Boris D. 1971. Fundamentals of social - psychological theory. Moscow, Mysl' Publ. (In Russian) Romashov, Roman A., Arbuzova, Svetlana A. 2013. "Regulatory and legal foundations and law instruments for penal resocialisation". Vestnik Vladimirskogo iuridicheskogo instituta 4 (29): 46-52. (In Russian)

Sergeev, Danil N. 2013. "Is a probation law necessary?" Iuridicheskaia nauka i pravookhranitelnaia praktika 3 (25): 68-72. (In Russian)

Varentsova, Larisa Y., Varentsov, Sergey Y. 2011. "From the History Nizhny Novgorod Provincial Guardianship of Prisons Committee in the $19^{\text {th }}$ - the beginning of $20^{\text {th }}$ century". Izvestiia vysshikh uchebnykh zavedenii. Povolzhskii region. Gumanitarnye nauki 3 (19): 12-18. (In Russian)

\section{Authors' information:}

Roman A. Romashov - Dr. Sci. in law, professor; romashov_tgp@mail.ru Elena A.Bryleva - PhD in law, associate professor; elenbrylev@yandex.ru 